\title{
Assessment of the Restoration of the Remolar Dune System (Viladecans, Barcelona): The Resilience of a Coastal Dune System
}

\author{
Antoni Calafat ${ }^{1, * \mathbb{D}}$, Sara Vírseda ${ }^{2}$, Raúl Lovera ${ }^{3}$, Joan Ramon Lucena ${ }^{4}$, Carme Bladé ${ }^{2}$, Lluís Rivero ${ }^{3}$ \\ and Josep M. Ninot ${ }^{2}$ (D) \\ 1 Departamento de Dinàmica de la Terra i de l'Oceà, Facultat de Ciències de la Terra, Universitat de Barcelona, \\ C/Martí i Franqués s/n, 08028 Barcelona, Spain \\ 2 Departamento de Biologia Evolutiva, Ecologia i Ciències Ambientals, Facultat de Biologia, \\ Universitat de Barcelona, Avda. Diagonal 643, 08028 Barcelona, Spain; saravirse@hotmail.com (S.V.); \\ cblade@ub.edu (C.B.); jninot@ub.edu (J.M.N.) \\ 3 Departamento de Mineralogia, Petrologia i Geologia Aplicada, Facultat de Ciències de la Terra, Universitat de \\ Barcelona, C/Martí i Franqués s/n, 08028 Barcelona, Spain; rlovera@ub.edu (R.L.); lrivero@ub.edu (L.R.) \\ 4 Area de Medi Ambient, Ajuntament de Viladecans, 08840 Viladecans, Spain; jrlucenas@viladecans.cat \\ * Correspondence: antonicalafat@ub.edu
}

check for updates

Citation: Calafat, A.; Vírseda, S.; Lovera, R.; Lucena, J.R.; Bladé, C. Rivero, L.; Ninot, J.M. Assessment of the Restoration of the Remolar Dune System (Viladecans, Barcelona): The Resilience of a Coastal Dune

System. J. Mar. Sci. Eng. 2021, 9, 113. https://doi.org/10.3390/jmse9020113

Academic Editor: Patrick Hesp

Received: 24 November 2020

Accepted: 19 January 2021

Published: 22 January 2021

Publisher's Note: MDPI stays neutral with regard to jurisdictional claims in published maps and institutional affiliations.

Copyright: (c) 2021 by the authors. Licensee MDPI, Basel, Switzerland. This article is an open access article distributed under the terms and conditions of the Creative Commons Attribution (CC BY) license (https:/ / creativecommons.org/licenses/by/ $4.0 /)$.
Abstract: The Remolar beach-dune system (700 m long and more than $100 \mathrm{~m}$ wide, $070 \mathrm{~N}$ direction) borders a campground that was closed (2003), due to the Barcelona airport expansion. In order to recover and restore the dune ecosystem, a series of soft measures were performed. After 10 years, a study of the morphology, sedimentology, and vegetation of the ecosystem was carried out to evaluate the results of these measures. For this purpose, a series of topographic and groundpenetrating radar (GPR) profiles, grain-size analysis, and an analysis of plant communities found along the profiles were carried out. The data obtained were compared with data from a former 2004 study. The results show that the morphology of the dunes recovered, and a new primary dune has arisen. The system now has a greater process of aggradation than of progradation. The vegetation has recovered the global composition of dune systems, with a typical community of embryo dunes and others of primary dunes that are set in strips parallel to the coast. Despite this improvement, the opportunistic and ruderal component in the primary dune vegetation evidences a strong anthropic inheritance in the system.

Keywords: dune restoration; geomorphology; plant communities; primary succession; remolar beach-dune system; Barcelona

\section{Introduction}

The economies of Mediterranean countries show a high dependence on the tourism industry. This dependence leads to overexploitation of coastal resources and especially the beach-dune systems. Human actions with an impact on the sandy coasts and their dunes are gathered in five groups [1]: (1) Housing and recreation; (2) industrial and commercial use; (3) waste disposal; (4) agriculture, aquaculture, and fisheries; and (5) military activities. The effects of tourism on coastal ecosystems and specifically on the degradation of coastal dune systems have been treated by different authors [2-4], among others. The coastal squeeze $[4,5]$ to which these environments are subjected, due to the long-term processes as sea-level rise, land subsidence, sediment deficit, and anthropic infrastructures jointly to the different tourism activities that take place there (bath, bars and restaurants, toilets and showers) and the management needs (mechanical cleaning of the beaches, construction of breakwaters, artificial feeding of the beaches...) cause its slow and progressive physical and biological degradation. These activities alter natural processes and coastal dynamics, 
eliminate topographic variability, fragment, degrade or eliminate habitats, reduce diversity and threaten endemic species $[6,7]$.

In Spain, studies on the degradation of coastal dunes date back to the 1970s, see the compilations from References [8,9] for an overview, and in recent years the interest and popular pressure for the protection and restoration of coastal dunes are exemplified by the publication of the "Coastal dune restoration manual" [10] by the Ministry of the Environment. In recent years, and due to the number of dune restoration projects that have been carried out on the Spanish coast, different works have been published on the state of vulnerability, and the assessment of different restoration projects, both on the Atlantic [11-14] and Mediterranean coasts [15-18].

In littoral geomorphology, the restoration projects of coastal dunes try to achieve a recovery of the exchange of sediment between the beach and the dune (foredune) and recover the dynamic profile of the beach-dune system. Natural ecosystem restoration occurs through similar processes that affect the integrity, functionality, and resilience of the ecosystem [6]. After Putsy and Silveira [19], the objective of foredune restoration is to restore the heterogeneity of features in the temporal context. This heterogeneity is achieved by the continual evolution of the beach-dune system. According to SER and UICN [20,21], the main methods used in the evaluation of restoration include the study of the ecosystem through: (i) The structure and composition of the plant community; (ii) species during plant succession; or (iii) the resilience after natural regeneration of the restored ecosystem.

These systems, due to their high dynamism, would have to present a high degree of resilience at the first and early stages. The term "resilience" [22] is used here as "the ability to recover the initial state from a disturbed state to the cessation of the disturbance that caused the change of state" [23]. Coastal managers are interested in landform development (abiotic barrier) over yearly to decadal temporal scales [21,24], but coastal dunes are systems where multiple interacting controls, internal and external to the system, occur at different scales. In a dune system, the goal of the different measures applied is to recover both the geomorphological dynamics, which includes the recovery of morphologies of this type of system, and the activity of the sedimentary dynamics represented by the transport and deposition of sediment, as well as the development capacity of its plant community, characteristic of each of its sub-environments. The recovery and/or restoration of a disturbed site can be approached through different methodologies, in relation to its initial state, the degree of affectation, and the time that has elapsed since anthropic activity ceases [25].

In this case, spontaneous succession or passive re-vegetation was sought, where colonization and natural succession of plants are allowed, and human action did not intervene. The use of spontaneous vegetation succession in an ecological restoration program requires different points to be addressed [26], such as: (1) Objectives, processes, and time frame within which the restoration objectives must be achieved; (2) environmental characteristics of the site and how these may or may not influence the succession; (3) the degree of possible generalization and the level of predictability between sites and patterns of succession; (4) communication between the different acting parties (researchers, professionals and authorities, including education and public awareness; and (5) post-project monitoring and evaluation. The monitoring allows us to monitor the development of the restored dune vegetation and to compare the composition and abundance of exclusive dune species with those of the reference dune systems [12].

The measures proposed for the recovery and restoration of the coastal dune system were and are those of soft management: (i) Prohibition of visitors from walking or crossing the dunes; (ii) delimitation of the dune zone with posts and ropes. Visitors can use the beach for swimming or sunbathing, provided that they use the permitted trails and do not enter the dune area; and (iii) manual cleaning of anthropic remains and inappropriate litter that reaches the beach. In the dune zone, cleaning actions are carried out even more carefully-i.e., less frequently. The proposed actions represent a greater effort of 
supervision by the environmental authorities, but the dune systems may have more value as habitats if they host sub-environments representative of natural gradients [27].

In this work, we studied the resilience capacity of the coastal dune system from the protected area of the beach of Remolar (Viladecans, Barcelona), taking into account the evolution of morphology and vegetation of the dune system at decennial term. This started in 2003, when a drastic change in the use of this beach took place, since the enlargement of the Barcelona airport led to closing the direct arrival paths to the beach, and thus, to a dramatic decrease of the leisure use of the beach. The following year, a study was carried out consisting of the realization of topographic profiles and a study of the vegetation of the dune system [28]. Ten years later, a comprehensive study was performed to evaluate the dynamics of the dune system.

\section{Study Area}

Remolar beach has a well-developed dune-beach system, linked to the fluvial plain of the Llobregat River [15,29]. It is located on the southern lobe of the Llobregat River delta, $5.7 \mathrm{~km} \mathrm{SW}$ from the mouth. The Llobregat river has a typical Mediterranean regime [30], influenced by seasonal (autumn) and sporadic torrential rainfalls. The southern lobe of the Llobregat river delta has a shoreline about $17 \mathrm{~km}$ long. The construction of infrastructures, notably the Barcelona airport, the extension of Barcelona harbor, and the growth of industrial and urban areas in the delta and its surroundings, transformed their landscape [30].

The southern Llobregat delta functions as a littoral cell. With the contribution of sediment at the mouth of the river, the port of Barcelona with its piers makes it impossible to transport sediment from the north, which on the southern hemi-delta coast is from ENE to WSW. The end of the littoral cell is the port of Ginesta (built from 1986) acts as a littoral drift barrier, where we find the widest beaches in the delta, reaching more than $150 \mathrm{~m}$ [31].

The beach of Remolar has a length of $700 \mathrm{~m}$ and is limited by the breakwater dams that protect the inlet from the lagoon of Remolar to the NE and the channelized stream of Sant Climent to the SW. The beach-dune system has a width greater than $110 \mathrm{~m}$, of which between 70-93 $\mathrm{m}$ are occupied by the dune system and the rest by the beach (Figure 1). In total, the Remolar beach-dune system takes an area of about $75,000 \mathrm{~m}^{2}$, of which $53,000 \mathrm{~m}^{2}$ were occupied by the dune system in 2013. From 1960 to 2004, the dune system was limited on its landward side by a fence, still existing, that delimited a campground. This fence had several direct exits to the beach. The result (Figure 1) was a degradation of the dune system in the occupied area (decreasing until 42,000 $\mathrm{m}^{2}$ in 2003), in the dune morphology, and in its vegetation cover. The extension of the Barcelona airport involved the cessation of the activity of the camping and the entrance as manager of the beach of the Environmental area of the City Council of Viladecans.

The characterization of the dynamic agents (wind and waves) of the study area has been carried out using data from the official web "Puertos del Estado" of the Ministry of Transport, Mobility and Urban Agenda of the Government of Spain (http:/ /www. puertos.es/es-es/oceanografia/). The wind system in the area is dominated by the dipole ENE (10\%)-NE (7.5\%) and SW (9\%)-WSW (8\%) directions (Figure 2a). The modal wind speed is between $2-3 \mathrm{~m} \cdot \mathrm{s}^{-1}\left(7.2-10.8 \mathrm{~km} \cdot \mathrm{h}^{-1}\right)$, the maximum values exceed $22 \mathrm{~m} \cdot \mathrm{s}^{-1}$ $\left(79.2 \mathrm{~km} \cdot \mathrm{h}^{-1}\right)$ and centered its presence during December and January. Waves (Figure $2 \mathrm{~b}$ ) are characterized by a significant height (Hs) of less than $0.5 \mathrm{~m}(51 \%)$ and a period of between $4-5 \mathrm{~s}$. The predominant directions are from SW (16\%) and E (15\%), and only $4 \%$ of the waves exceed $1.5 \mathrm{~m}$, the predominant storms being in E-ENE direction. The activity of the storms has been controlled based on the maximum Hs time series, between the periods 2004-2013 (Figure 2c). From the series, it is extracted that in the decade studied, there have been 39 storms greater than $2.0 \mathrm{~m}$ of $\mathrm{Hs}$, wave height that is considered a storm on the coast of the Llobregat delta [32,33], 14 with a height greater than $3.0 \mathrm{~m}, 5$ greater than $3.5 \mathrm{~m}$, and 3 greater than $4.0 \mathrm{~m}$. These storms cause a run-up [34] of between $0.6-1.5 \mathrm{~m}$ for $\mathrm{Hs}>2.5 \mathrm{~m}$ and a rise of 1.0-2.4 $\mathrm{m}$ in storms of $\mathrm{Hs}>4.0 \mathrm{~m}$. Such run-up heights are capable 
of producing complete erosion of the embryonic dunes and producing erosion scarps and washover deposits in the primary dune.
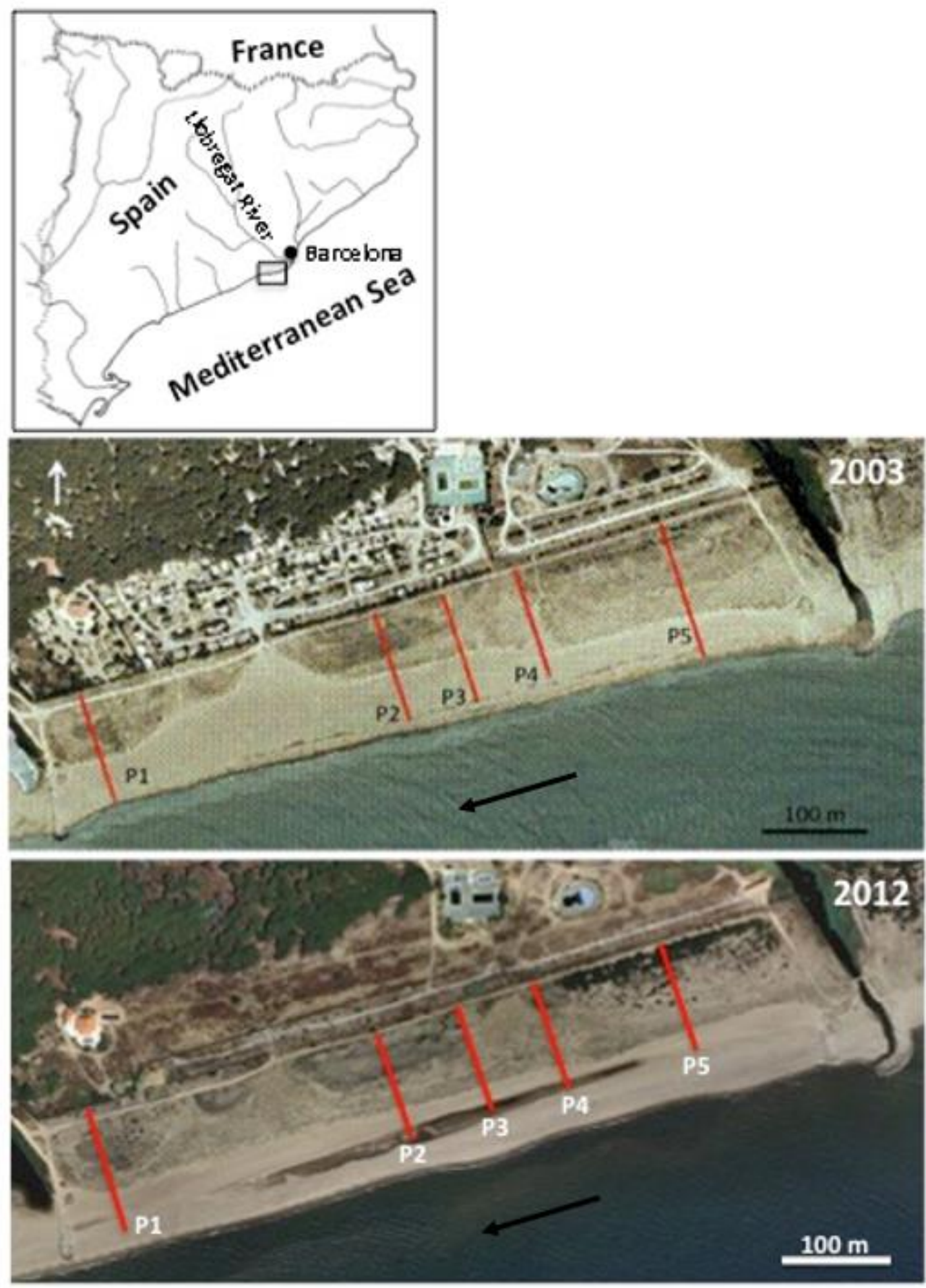

Figure 1. Location of the study area, box south of the Llobregat River and aerial view of the beach of Remolar in years 2003 and 2013 (http:/ / www.icc.cat/vissir3/). The regression of the dune system in 2003 is evidenced, mainly due to the trampling on the dunes. On this view, the red lines (P1 to P5) indicate the topographic and vegetation profiles; grain-size distribution analysis was performed in P1 and P5, and ground-penetrating radar (GPR) profiles were realized in P1 and P2. The 2013 photo shows how both the morphology of the dune zone and the vegetation in the area have increased and stabilized. The black arrow, south of the coastline, indicates the predominant direction of the coastal drift at Remolar beach, in the ENE-WSW direction. 


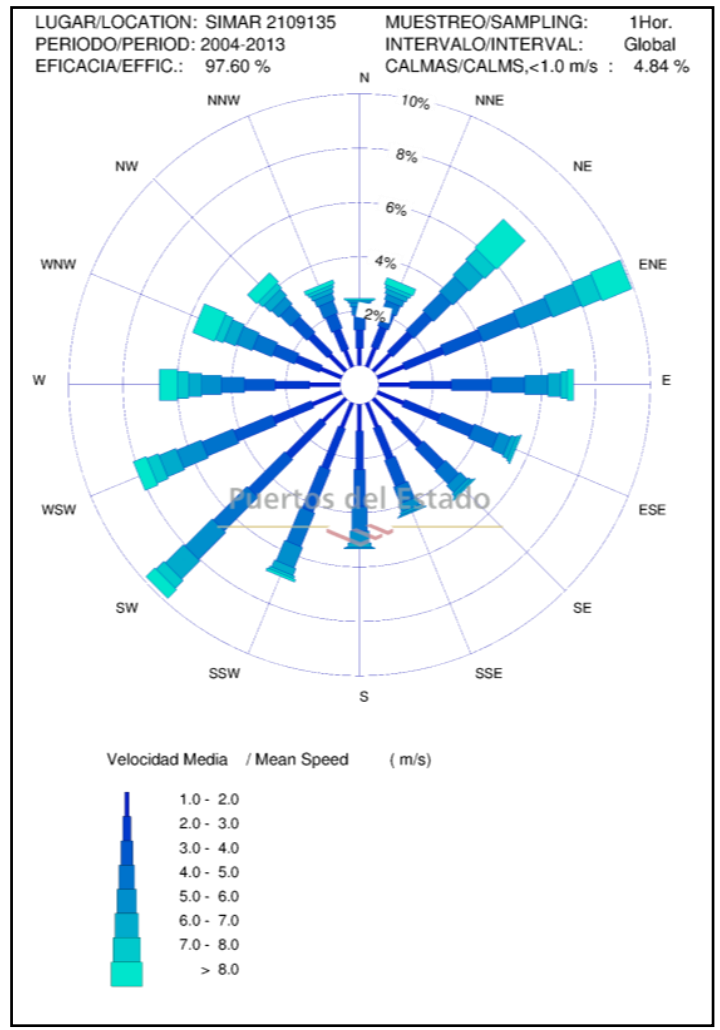

(a)

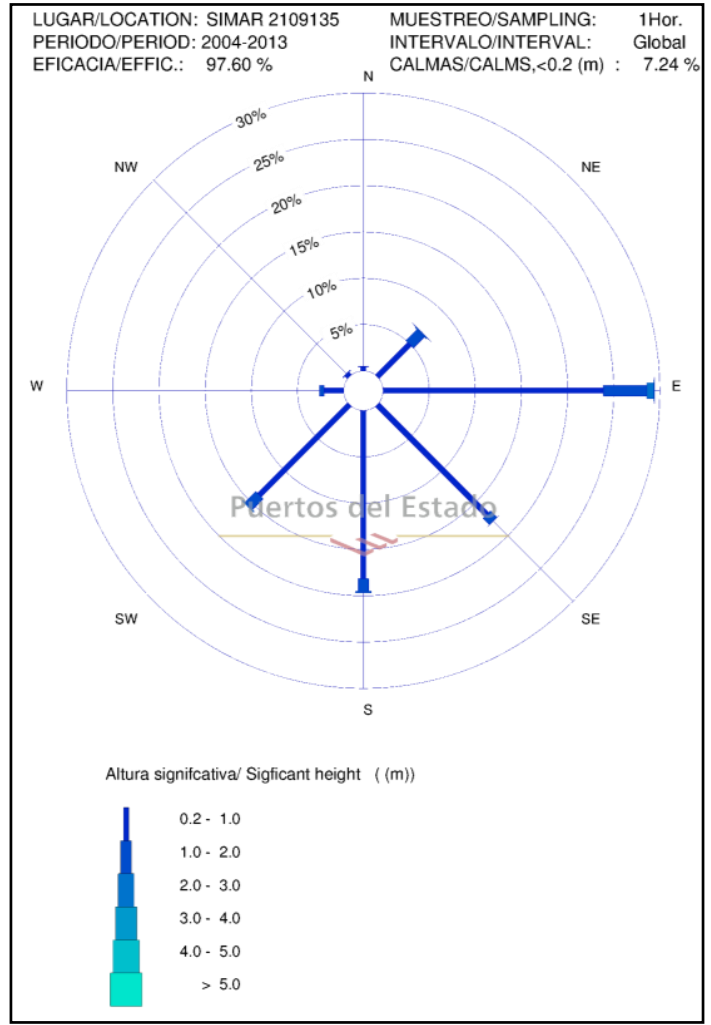

(b)

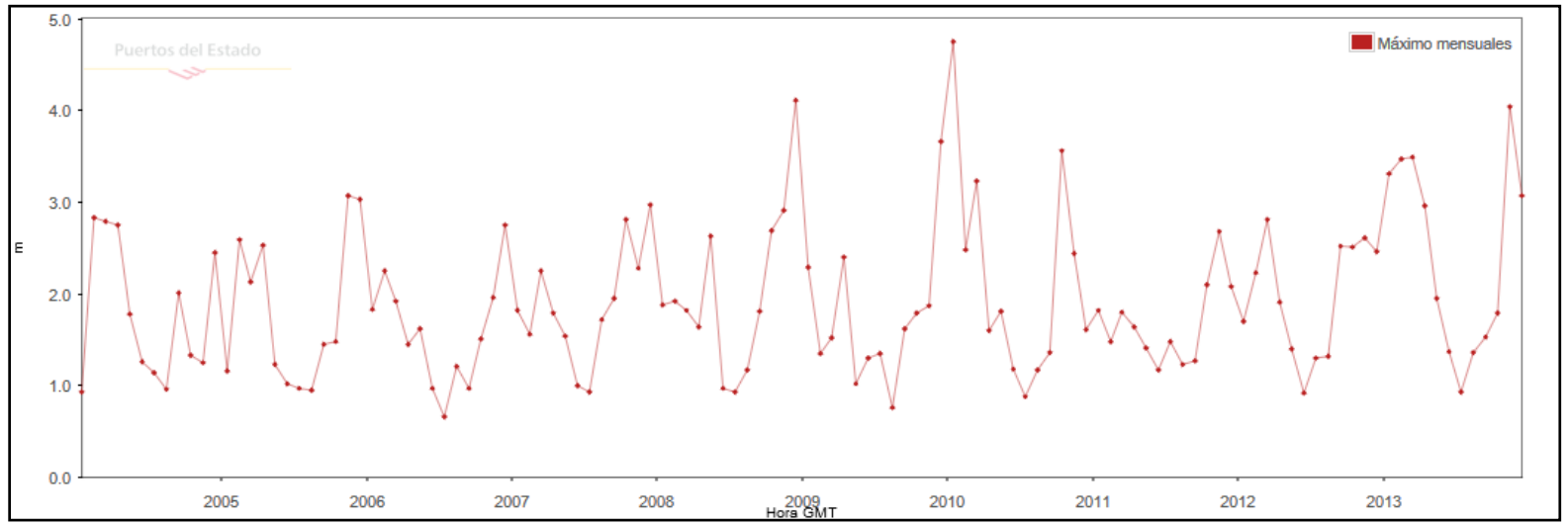

(c)

Figure 2. Meteorological data of the beach-dunes system of Remolar. The data from point SIMAR 2,109,135 $\left(41.25^{\circ} \mathrm{N}, 2.08^{\circ} \mathrm{E}\right)$ was collected from the Puertos del Estado website (http:/ / www.puertos.es/es-es/oceanografia/Paginas/portus.aspx) of the Ministry of Transport, Mobility and Urban Agenda. (a) Wind rose, between 2004 and 2013; (b) rose of the swell of significant height (Hs in $\mathrm{m}$ ) between the years 2004 and 2013; and (c) time series of the monthly mean of the maximum significant height (Hs max. in m), between 2004 and 2013.

Following the aforementioned recommendations by Reference [26], we present a reference model of the spontaneous vegetation of the dunes in the studied area of the Remolar beach, and it is important to consider the distribution of plant communities on a beach where disturbance has been minimal. The dunes studied in the Remolar area are classified within the type of "dune ridges with semi-fixed dunes" according to Reference [29]. Following several authors [29,35] the model of plant communities found is: (1) Agropyretum mediterraneum, the grass-sand community in the embrionary dunes; (2) Ammophiletum arundinaceae, the community of marram grass located on the top of the dunes, with species, such as Ammophila arenaria - marram grass- and Pancratium maritimum; 
(3) Crucianelletum maritimae, the community located on the leeward side of the primary dune, the secondary dune and more stabilized dunes; and these give way to (4) pinewood (stands of Pinus pinea, at places planted by man) or to juniper scrub.

\section{Methods}

To assess the impact of the measures implemented on the dune ecosystem, between 2013 and 2014, we carried out a study of the state of the (1) morphology, through topographic surveys; (2) grain-size distribution of the dune system; (3) internal structure of the dunes, using GPR (ground-penetrating radar) profiles; and (4) dune vegetation, in terms of plant communities. All this information has been compared with the work of Gonzalez et al. [28]. The methodology used to carry out the topographic profiles and vegetation studies has also been the same.

The methodology to carry out the topographic profiles is the same used by Reference [28] in a previously performed study, namely, we performed five transects located perpendicular to the coast (Figure 1). A spatial reference system was created using $2 \mathrm{~m}$ high wooden rods, firmly fixed every $10 \mathrm{~m}$ along with the profile, and joined by a rope that was kept horizontal with the help of a bubble level. Height measurements were taken from the rope to the sand every $20 \mathrm{~cm}$, considering the sea-level as $0 \mathrm{~m}$ high. The validity of the system is verified by the good correlation in the profiles of the different years in the first meters, an area crossed by a path of compacted material that has not changed over time (Figure 1). Due to the soft behavior of sand, topographic measurements can have up to $1 \%$ percent error, which is carried over into volume calculations. The topographic profiles of the two study years have been compared both volumetrically and morphologically. Volume calculations referred to sand gains, or losses have been made per linear meter of profile $\left(\mathrm{m}^{3} \cdot \mathrm{m}^{-1}\right)$.

The characterization of the surface grain size was performed in profiles 1 and 5, collecting samples distributed along with each topographic profile, 15 and 14 samples per profile, respectively. The samples were analyzed by a COULTER LS230 laser diffractometer, and their system software supplied the main statistical parameters as the mean $(\bar{x})$, the mode, and the standard deviation $(\sigma)$. The grain size analysis implies a pre-treatment of the sample with $\mathrm{H}_{2} \mathrm{O}_{2}$, for the elimination of organic matter, and shaking the sample with sodium pyrophosphate avoids flocculation. To know the dynamics of the sediment and its classification, due to transport using the wind, the sorting or classification parameter was calculated based on the mean $(\bar{x})$ and standard deviation $(\sigma)$ (Thus: $\bar{x}+\sigma / \bar{x}-\sigma$ ), similar to the sorting parameter of Trask [36], where lower values indicate better sediment classification. The relationship between the mean grain size and the dispersion of the sample is visualized by the coefficient of variation $\left(\mathrm{CV}:(\bar{x} / \sigma)^{*} 100\right)$.

The present work gives us the opportunity to study the regenerated dunes both in their morphological and sedimentological dynamics. For this and to know the internal structure of the new dune bodies, GPR transects were made in profiles 1 and 2. A Georadar (SIR 3000) was used, equipped with two types of antenna that provide data of the signal that was processed, filtered, and amplified. This allowed us to analyze and visualize the different sedimentary levels in the subsoil. In this work, an antenna of $400(\mathrm{MHz})$ was used. Thus, the RPM (reflection profiling mode) configuration was used. Said configuration consists of two mobile antennas that are separated by a fixed distance along the surface of the terrain. These antennas send pulses (shots) to the ground and capture the reflection signal. All shots were stacked and displayed in the GPR profile. The signals obtained have been clear throughout the profile. GPR data is processed for correction of low-frequency and DC bias in data (Dewow), for correction of start time to match with surface position (time zero correction) and filtered to remove noise from the acquired signal and to improve and visual quality (filtering 1D and 2D). Furthermore, the radargram is adapted to the terrain topography and selected for the appropriate gains for data display and interpretation. The penetration depths depend on the propagation velocities, and these on the dielectric properties of the sediments. For sands, such as those of dune-beach systems, propagation 
velocities of 0.10 to $0.20 \mathrm{~m} \cdot \mathrm{s}^{-1}$ have been proposed [37,38]. In coastal dunes, changes in the dielectric properties of sediments are produced by saturation with seawater [38]. In the present work, to favor resolution against penetration, a $400 \mathrm{kHz}$ antenna has been used, as indicated above, and we consider a penetration of $0.2 \mathrm{~m} \cdot \mathrm{ns}^{-1}$ and a resolution of less than $20 \mathrm{~cm}$. With this resolution, the reflections can be interpreted as the product of primary depositional fabric and sedimentary structures [39].

Sampling and collection of vegetation data were carried out at different visits during May 2014, within the period of maximum growth and flowering (March-July). For the sampling of plant communities, we set squares of $0.5 \times 0.5 \mathrm{~m}$ every $2 \mathrm{~m}$ in each of the profiles, from the point of origin (inland fence) to the point of absence of vegetation, $70-100 \mathrm{~m}$ length, and between 39-47 quadrants per profile with a total of 225 quadrants for the entire study area. In each square, we obtained a vegetation inventory, namely, we recorded a complete list of the species present and evaluated their abundance in terms of cover. For this, we used a simplified scale of three value ranges, inspired in the phytosociological method, with the following meaning: (1) For a covering between $0-10 \%$; (2) for a covering between $10-50 \%$; and (3) for a covering between $50-100 \%$.

Since vegetation analysis was through Fuzzy groups, where the species cover values have a low weight in front of their presence, we preferred this value simplification to obtain more inventories. The analysis of the plant communities has been carried out using the statistical software GINKGO [40,41], in order to form groups of related inventories according to their plant species composition. Then, we assembled these vegetation groups to the phytosociological schemes of vegetation $[28,40]$. For the allocation of the inventories to each group (plant association), we used the GINKGO fuzzy clustering analysis (Fuzzy-c Means algorithm). The grouping criterion to obtain the optimal fuzzy partition (number of inventory groups) is associated with the least squared error function, which produces a Bray-Curtis distance matrix. The descriptive determination of the communities has been carried out considering the results of the matrix of the Phi coefficient of fidelity $(\varphi)$ [42]. "Fidelity" is the degree of preference of each species to each given plant association.

The representation of the results obtained in the statistical analysis on the vegetation has been plotted on each profile. Then, with the support of field assessment and current orthophotos, we interpolated the distribution of the vegetation units between profiles, to draw up a vegetation map. The data treatment has been processed with the Geographic Information Systems software gvSIG.

\section{Results}

\subsection{Morphology}

The comparison of topographic surveys between 2004 and 2013 (Figure 3) shows an evident variation in all profiles. At a general level, all the profiles show general aggradation and more limited progradation. Although, if we visualize the set of orthophotos (from 2004 to 2013), an increase in the dune surface is observed, the increase in sand volume has not been generalized (Table 1), profiles 1,2, and 4 show a similar increase of between 47.4, 42.4 and $40.8 \mathrm{~m}^{3} \cdot \mathrm{m}^{-1}( \pm 1 \%)$, respectively. While in other areas, profiles 3 and 5 , losses of 9.9 and $8.0 \mathrm{~m}^{3} \cdot \mathrm{m}^{-1}( \pm 1 \%)$, respectively, have been quantified.

Inspection of topographic profiles and aerial photographs (Figures 1 and 3) indicate the presence of two to four dune ridges set approximately parallel to the coastline. All the profiles show the presence, in the year 2013, of a dune ridge identified as primary dune, uninterrupted dune, located between 70 and $90 \mathrm{~m}$ depending on each profile (Figure 3). 


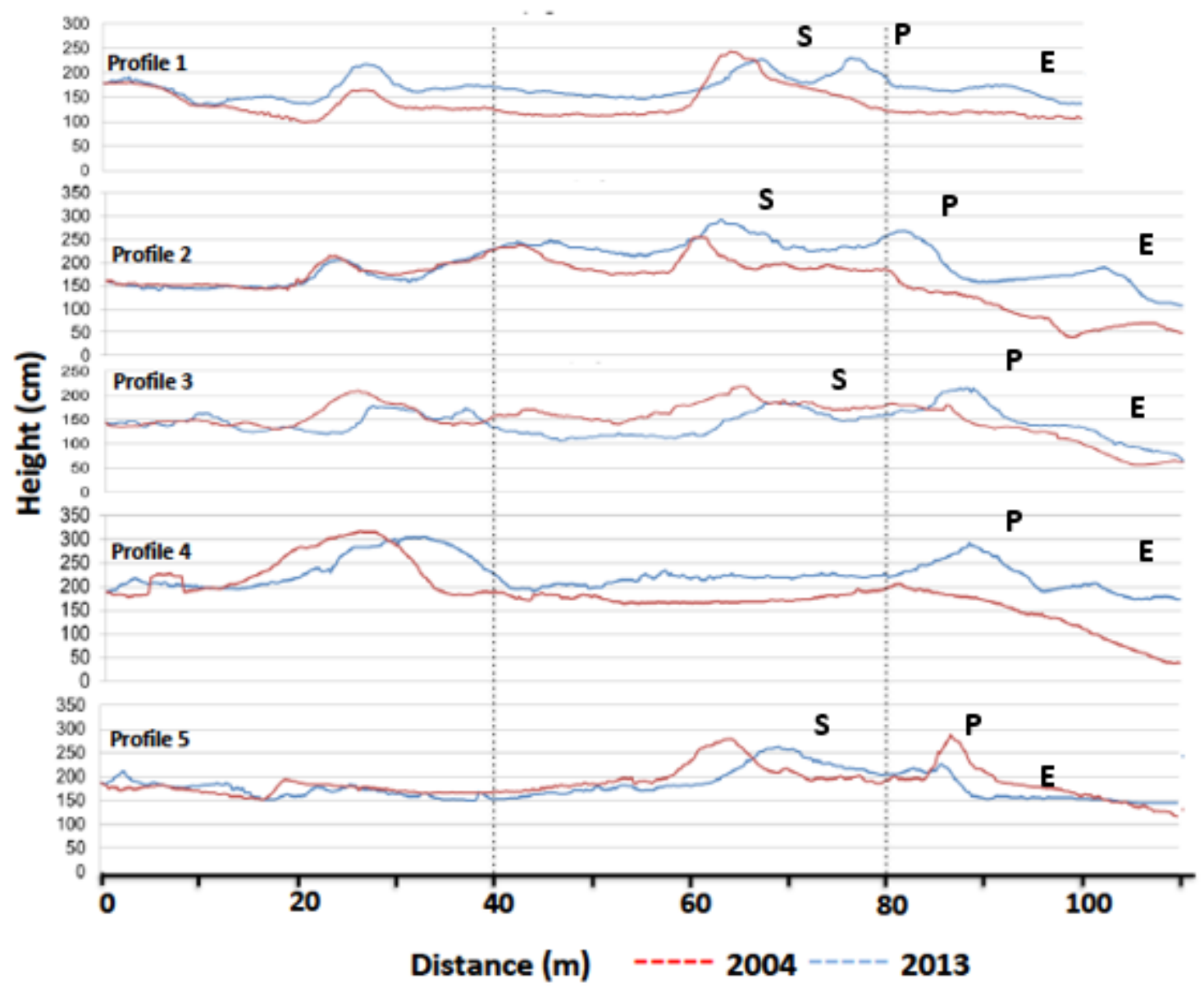

Figure 3. Topographic comparison of the five topographic profiles (see the location in Figure 1), between 2004 and 2013. Distance is measured from the landside limit of the dune system to the bare beach. Three to five dune ridges are observed in each, the most active being the secondary dune $(\mathrm{S})$ at ca. $65 \mathrm{~m}$., the primary dune $(\mathrm{P})$ at $75 \mathrm{~m}$, and the embryonic dune $(\mathrm{E})$ at $90 \mathrm{~m}$. Both the primary dune $(\mathrm{P})$ and the embryonic dune (E) have originated during these almost 10 years of regeneration measures.

Table 1. Volumetric changes, in cubic meters per linear meter $\left(\mathrm{m}^{3} / \mathrm{m}\right)$, in the profiles between 2004 and 2013.

\begin{tabular}{cc}
\hline Profile & Final Linear Volume $\left(\mathbf{m}^{\mathbf{3}} / \mathbf{m}\right)$ \\
\hline 1 & 47.4 \\
2 & 40.8 \\
3 & -9.9 \\
4 & 42.4 \\
5 & -8.0 \\
\hline
\end{tabular}

If we focus on the morphology, from sea to land, it is observed in all profiles the occurrence of an embryonic dune (foredune), marked with E in Figure 3, and a primary dune, marked with $P$ in Figure 3. This new primary dune reached between 0.75 and $1.5 \mathrm{~m}$ high and approximately $10 \mathrm{~m}$ wide. This new primary dune shows an asymmetric profile with a steeper slope on the seaside, due to erosion scarps caused by storms. In addition, the secondary dune shows a growth on the seaside in all the profiles, which results in a progradation of the ridge towards the sea (Figure 3) of about $5 \mathrm{~m}$. Between the primary and secondary dunes, an interdune depression (ID) is observed with a depth of $50 \%$ of the height of the dunes, while in the leeward (landside) of the secondary dune, we found the intermediate interdune depression (IID), with dimensions of length and height greater than ID. 


\subsection{Grain-Size Distribution}

The grain-size distribution of the dune system, of all 29 samples from profiles 1 and 5 , shows an average of $353( \pm 42) \mu \mathrm{m}$, while the beach has an average value higher than $400 \mu \mathrm{m}$ (Figure 4), the range of grain sizes of all samples fall within the class of medium sand of Wentworth [43]. Being the mode, a little higher, standing at $360.09( \pm 36.52) \mu \mathrm{m}$. Both the mean and the mode have low variation coefficients between $12 \%$ and $10 \%$, respectively. Sediments show a decrease in their mean diameter from sea to land, which can be interpreted as the majority of the sediment being supplied to the dune system from the dry beach area.

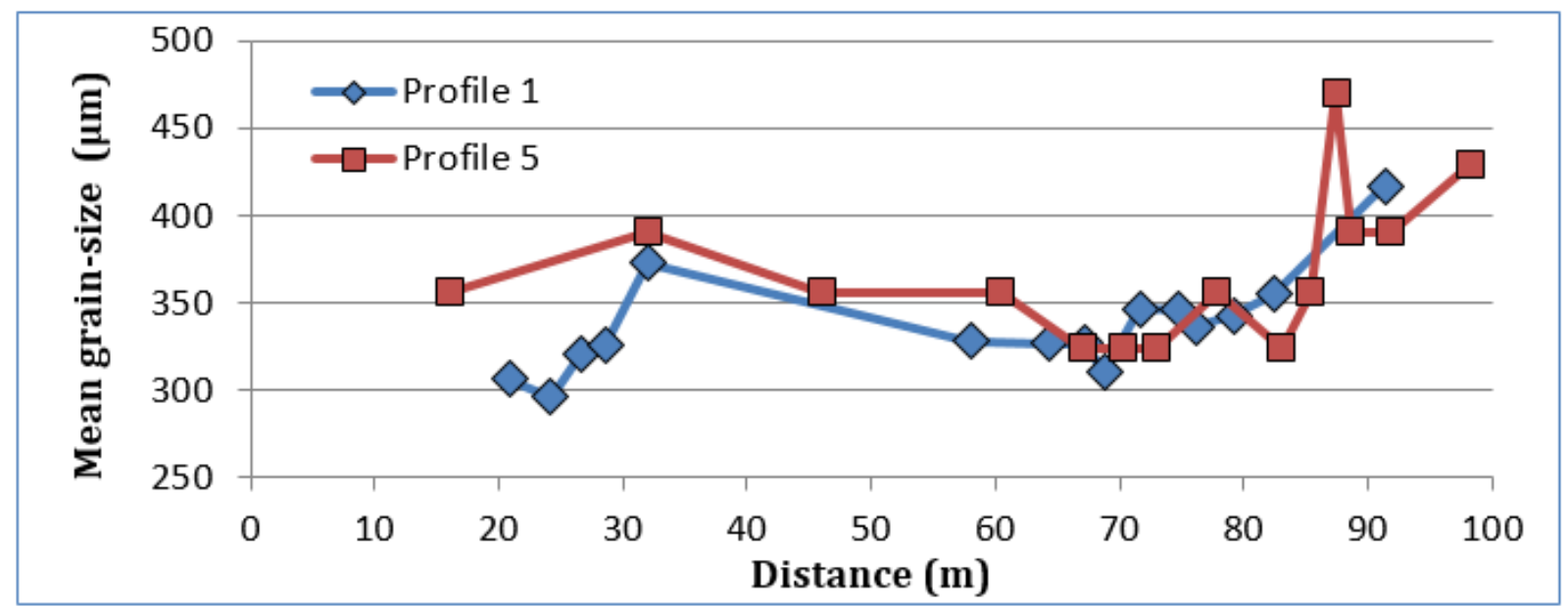

Figure 4. Evolution of mean grain size in the dune system with distance from the landside to the beach, in profile 1 (blue diamonds) and profile 5 (red squares). It is observed that the size increases from $70 \mathrm{~m}$ to $100 \mathrm{~m}$. The larger size of the two profiles corresponds to the ridges of the embryonic and primary dunes of profiles 1 and 5, respectively.

The sorting presents an average value of $2.29( \pm 0.27)$, with a coefficient of variation of $11.97 \%$. Sediments were better sorted (lower values) when they were closer to the active areas of the embryonic dune or on the dry beach (Figure 5A), as indicated by the decrease in values from land to beach. The mean size and the sorting (Figure 5B) show a lack of relationship. The sediments were better sorted (lower values) when they were closer to the active areas of the embryonic dune or on the dry beach (Figure 5A), as indicated by the decrease in values from the landside to the beach.
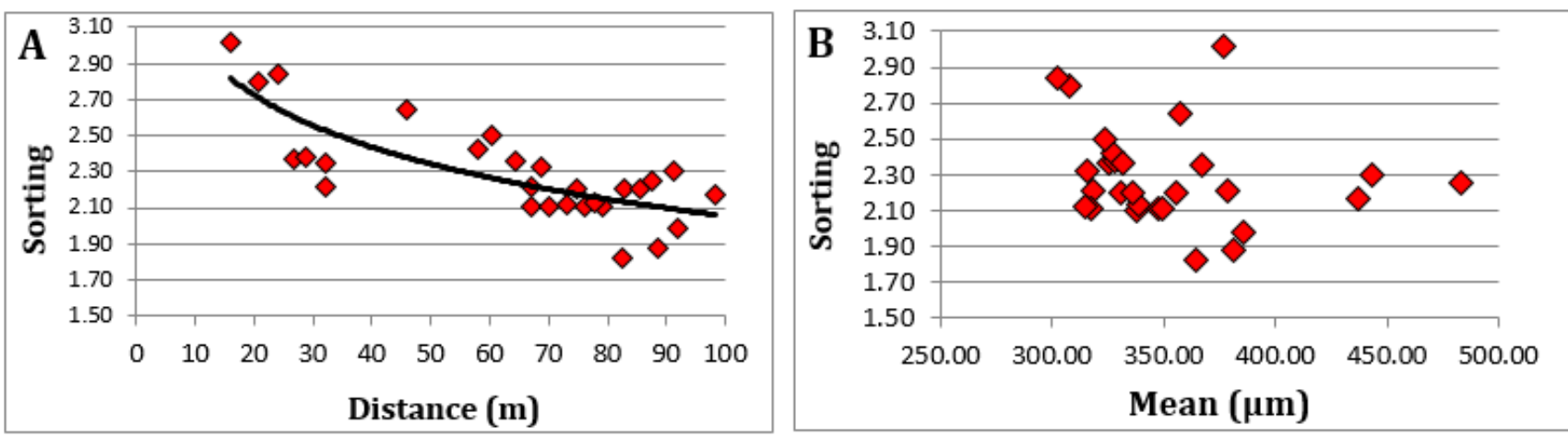

Figure 5. (A) Variation of sand sorting with respect to the distance from the landside to the beach, showing a clear decrease (better classification) in the samples located in the primary and embryonic dunes. (B) Graph of the relationship between mean size and sorting of the sand grains, giving no correlation between the two parameters. 


\subsection{GPR Profiles: Dune Internal Structure}

The GPR profiles have been worked according to the methodology of Bistrow et al. [38]. This methodology differentiates a series of radar facies and associates them with certain sedimentary processes (Figure 6). In our profiles, we have differentiated six radar facies (RF), which we describe as: RF1 (discontinuous lower amplitude curved concave-up) indicating reworking processes and/or filling of furrows; RF2 (discontinuous, low-angle clinoforms at the stoss side of the dune, with seawards dips) interpreted as sedimentary accretion on the seaside; RF3 (discontinuous subhorizontal, gently dipping reflectors at the lee face of the dune with dips towards the landward) interpreted as roll-over of aeolian deposits formed by sand eroded from dune crest or from storm washover deposits; RF4 (low amplitude, discontinuous concave and convex-up undulating), due to sedimentary accumulation with vegetation; RF5 (continuous low-angle clinoform sea-ward dipping) interpreted as beach deposits; RF6 (short landward/seaward dipping) interpreted as beach bars.
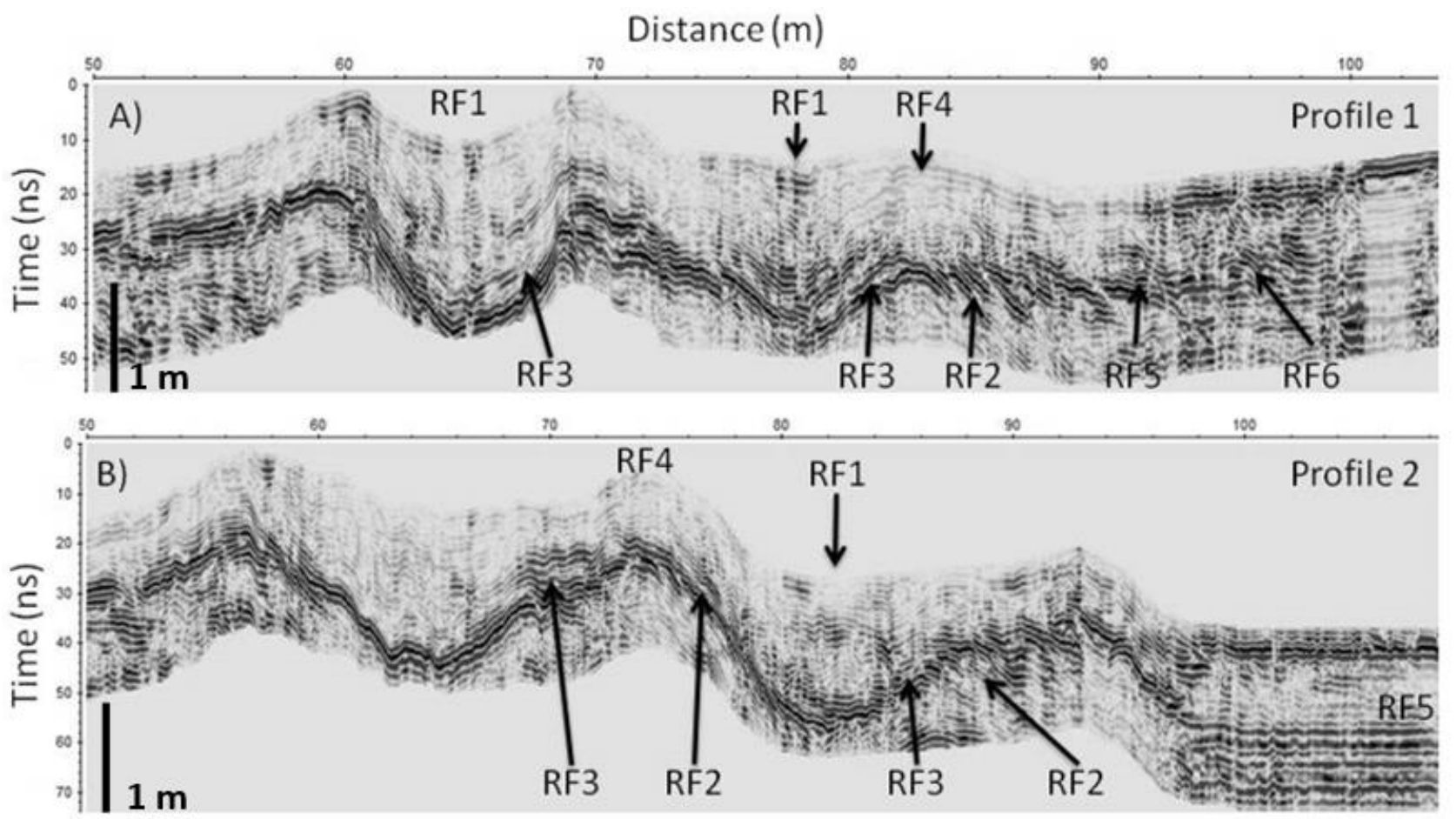

Figure 6. Terminal section of the GPR profiles from land (left) to sea (right), from the mid dune system to the beach: (A) Profile 1, and (B) Profile 2, (see Figure 1 for location). On the profiles are indicated the different radar facies used in their interpretation (described in the text). RF1 facies is the result of the filling of interdune grooves, RF2 facies show wind deposits in the seaside zone of the dunes, RF3 facies are deposits due to washover processes or aeolian deposits filling interdune depressions, RF4 is due to sedimentary accumulation with vegetation, and facies RF5 and RF6 are interpreted as beach deposits and the formation of berms or foreshore bars, respectively.

We have focused on the internal structure of the most active part of the dune system, shown in Figure 6, as the GPR radargrams performed in profiles 1 and 2 (see Figure 1 for location). In profile 1 (Figure 6A), the most marine area (from 90 to $100 \mathrm{~m}$ ), RF 5 and 6 , would indicate the occurrence of beach deposits (low-angle sea-ward dipping reflectors) and beach-bars (short seaward dipping), respectively. Meanwhile, towards the landside, the embryonic dune formation process is observed (between 84 and $90 \mathrm{~m}$ ), where the discontinuous reflector clinoforms with seawards dips (RF2) would indicate the sediment accretion process that occurs in the seaward of the dune. These reflectors are eroded in their upper part, by washover processes during storms, which are deposited as RF3 (dipping reflectors with dips towards the landward), filling the interdune depression. The accretion 
processes on the seaward side (RF2) and the deposition of sediments on the landward side (RF3) are observed to be repeated on both the primary dune $(70 \mathrm{~m})$ and the secondary dune $(60 \mathrm{~m})$.

In the marine area of profile 2 (more than $100 \mathrm{~m}$ in Figure 6B), the presence of RF 5 facies indicates the beach deposits (low angle reflectors and low inclination towards the sea). Towards the landside, the formation process of the embryonic dune is observed (between 85 and $95 \mathrm{~m}$ ), with processes of progradation and aggradation, in the internal structure of the dune, as indicated by RF2 facies. Later, the interdune depression is filled, since RF3 facies is found to fill the interdune depression. The filling is finished with reflectors RF1, curved concave-up, indicating filling of furrows.

\subsection{Vegetation}

The plant communities were species-poor at a small scale (mostly, 3 to 5 species per $0.25 \mathrm{~m}^{2}$ ). The whole flora recorded, however, was moderately rich (47 plant species), grace to the contrasting composition among vegetation spots. Table 2 shows the results obtained with the statistical analysis of the fuzzy grouping of the plant inventories done. Seven groups or different plant communities were obtained, which are partially interpreted as phytosociological associations already described for the coastal ecosystems of the area. The table shows the species that define each group, their fidelity value Phy $(\varphi)$ to that group-we have cut these lists from species with values below 0.1 , the minimum value of the fidelity coefficient given to a species to be considered as a "diagnostic species" [44] and the interpretation of the groups in phytosociological terms.

Table 2. Description of the plant community types found. The phytosociological names referenced follow the criteria of Rivas-Martinez et al. [45].

\begin{tabular}{|c|c|c|c|}
\hline Group & Main Species & $(\varphi)$ & Commumity-Association \\
\hline \multirow{3}{*}{1} & Pinus pinea & 0.94 & \multirow{3}{*}{$\begin{array}{l}\text { Pine forest with subordinate species } \\
\text { tolerant to shade }\end{array}$} \\
\hline & Aetheorhiza bulbosa & 0.13 & \\
\hline & Pleurochaete squarrosa (moss) & 0.10 & \\
\hline \multirow{4}{*}{2} & Medicago marina & 0.79 & \multirow{4}{*}{$\begin{array}{c}\text { Primary dune vegetation, assimilable } \\
\text { to Medicagini marinae-Ammophiletum } \\
\text { australis }\end{array}$} \\
\hline & Silene niceensis & 0.20 & \\
\hline & Cutandia maritima & 0.16 & \\
\hline & Eryngium maritimum & 0.13 & \\
\hline \multirow{5}{*}{3} & Elymus farctus & 0.76 & \multirow{5}{*}{$\begin{array}{l}\text { Embryonic dunes vegetation (Cypero } \\
\text { mucronati-Agropyretum juncei) }\end{array}$} \\
\hline & Calystegia soldanella & 0.32 & \\
\hline & Echinophora spinosa & 0.22 & \\
\hline & Polygonum maritimum & 0.20 & \\
\hline & Xantium italicum & 0.14 & \\
\hline \multirow{12}{*}{4} & Panicum repens & 0.73 & \multirow{12}{*}{$\begin{array}{l}\text { Secondary dune vegetation of fixed } \\
\text { environment-interdune } \\
\text { (Crucianelletum maritimae), with } \\
\text { chamaephytes and anthropic influence. }\end{array}$} \\
\hline & Scabiosa atropurpurea var. maritima & 0.34 & \\
\hline & Alyssum maritimum & 0.31 & \\
\hline & Centaurea aspera subsp. aspera & 0.25 & \\
\hline & Paronychia argentea & 0.25 & \\
\hline & Helichrysum stoechas & 0.22 & \\
\hline & Euphorbia terracina & 0.19 & \\
\hline & Pancratium maritimum & 0.16 & \\
\hline & Carpobrotus edulis & 0.13 & \\
\hline & $\begin{array}{c}\text { Corynephorus divaricatus subsp. } \\
\text { articulatus }\end{array}$ & 0.13 & \\
\hline & Cynodon dactylon & 0.13 & \\
\hline & Teucrium polium subsp. dunense & 0.13 & \\
\hline
\end{tabular}


Table 2. Cont.

\begin{tabular}{cccc}
\hline Group & Main Species & $\mathbf{(} \boldsymbol{\varphi})$ & Commumity-Association \\
\hline \multirow{4}{*}{5} & Cyperus capitatus & 0.68 & \\
& Plantago albicans & 0.32 & Opportunistic and ruderal \\
& Asphosdelus fistulosus subsp. Fistulosus & 0.12 & vegetation assemblage of the Cakilion \\
& Myoporum laetum & 0.12 & maritimae alliance with populations of \\
& Orobanche sp. & 0.12 & Cyperus capitatus \\
& Thymalaea hirsuta & 0.12 & \\
& Catapodium marinum subsp. Marinum & 0.12 & \\
6 & Medicago littoralis & 0.28 & Psamophilous vegetation of fixed \\
& Sporobolus pungens & 0.17 & environments like interdune \\
& Crucianella maritima & 0.15 & depressions (Crucianelletum maritimae) \\
\hline \multirow{4}{*}{ Ambrosia coronopifolia } & 0.84 & \\
& Bromus madritensis & 0.62 & Ruderal vegetation assemblage of the \\
& Vulpia membranacea subsp. fasciculata & 0.24 & Cakilion maritimae alliance with alien \\
Lagurus ovatus & 0.21 & species, such as Ambrosia coronopifolia \\
& Plantago lagopus & 0.20 & \\
\hline
\end{tabular}

The groups reflect vegetation associations or alliances, although not always clearly defined. Group 3 corresponds to the pioneering vegetation of the embryonic dune (Cypero mucronati-Agropyretum juncei Kühnholtz ex Br.-Bl. 1933). Group 2 reflects primary dune conditions, assimilable to Medicagini marinae-Ammophiletum australis Br.-Bl. 1921 corr. F. Prieto and T.E. Díaz 1991. Group 6 is not so defined, including mainly psammophilous species; it could be attributed to vegetation settling on with a more fixed environment, such as interdune depressions (Crucianelletum maritimae Br.-Bl. 1933).

The other groups are of complex attribution. On the one hand, group 4 corresponds mainly to the interdune depression (Crucianelletum), as it includes a good group of chamaephytic species, indicating a rather stable environment, although the strong fidelity of Panicum repens denotes an anthropized legacy, related to fixed, somewhat compacted soil. Groups 5 and 7 seem to respond to the dominance of each species, the first to populations of Cyperus capitatus with other more sporadic species (ruderal, opportunistic), and the second to formations of this same character, but dominated by the alien species Ambrosia coronopifolia. Both groups would be related to the unstable, somewhat ruderal herbaceous assemblages of the alliance Cakilion maritimae Pignatti 1953. Finally, the spontaneous implantation of Pinus pinea from neighboring pinewoods, in the form of seedlings to young trees, results in the appearance of group 1, defined by the pine and a few species tolerant to its shading. This is not any specific syntaxon, partly due to the small size of the inventories carried out, partly to their early development stage their represent.

The identified plant communities show a consistent arrangement in longitudinal bands (Figure 7), or vegetation zonation, perpendicular to the different transects and parallel to the coastline. The position of the embryonic dune vegetation stands out, in the form of a continuous strip, although of irregular width, near the coastline. The secondary dune vegetation is more irregular, disappearing in some sections, where the vegetation with a more stable environment (community with Crucianella maritima) contacts the embryonic dune community. We found a large area occupied by ruderal opportunistic communities, some of which holding non-native species, such as Ambrosia coronopifolia. It is also notable the presence of well-developed stands of pine forest. 


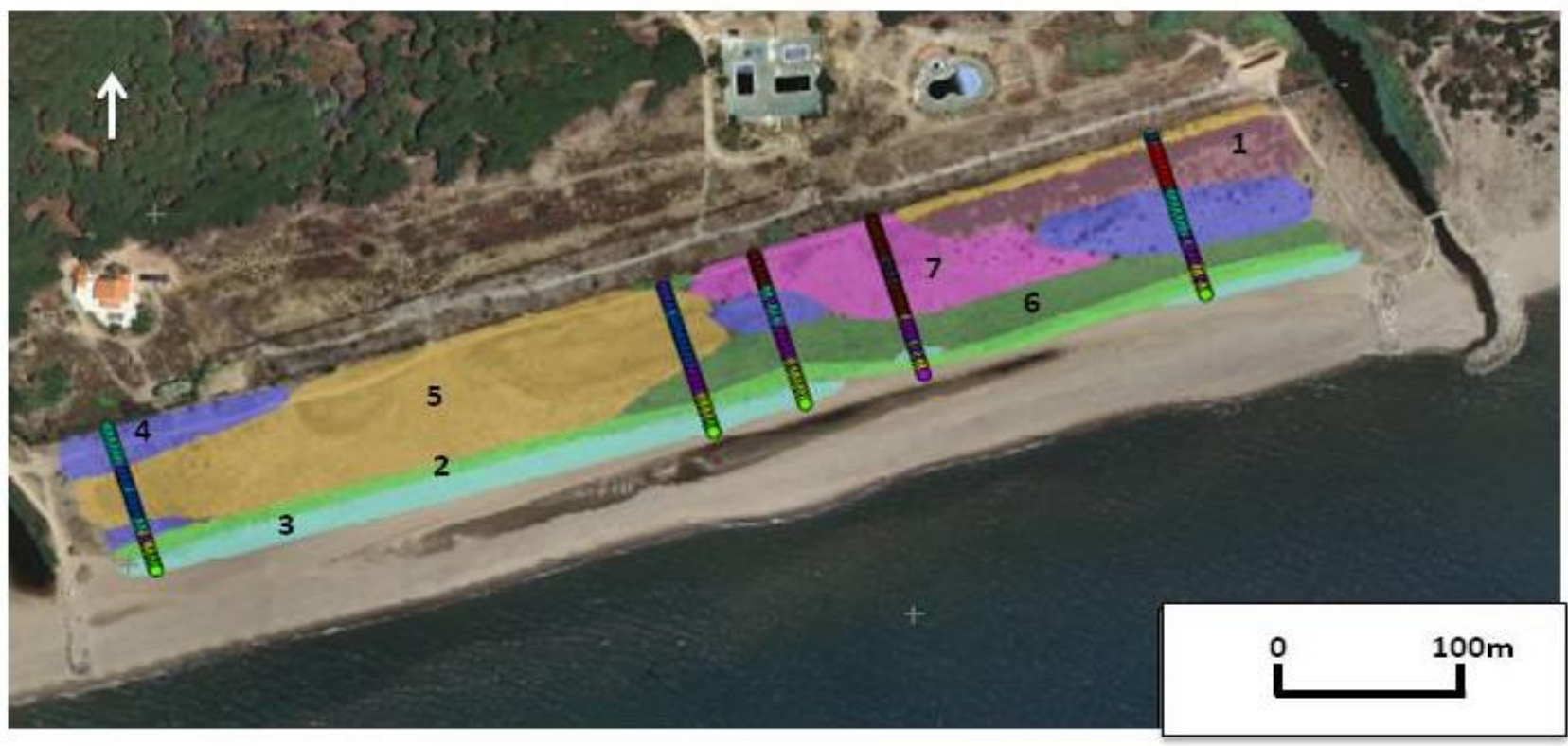

Figure 7. Map of the surface distribution of plant communities in 2013. The numbers represent the distinct communities differentiated in Table 2, and the colors the distribution of the communities. (1) Pine forest; (2) primary dune vegetation; (3) embryonic dunes vegetation; (4) secondary dune vegetation; (5) opportunistic and ruderal vegetation (Cakilion maritimae alliance with Cyperus capitatus); (6) psammophilous vegetation of interdune depressions; (7) ruderal vegetation (Cakilion maritimae alliance with Ambrosia coronopifolia). The distribution of the different communities clearly shows the arrangement in longitudinal bands parallel to the coastline of the primary dune (2) and embryonic dune (3) communities. The zones most affected by human trampling show communities of the opportunistic (5) and ruderal (7) type, which interrupt the distribution of the secondary dune (4) and inter-dune depression (7) communities.

\section{Discussion}

The abiotic and biotic characterization of the Remolar coastal dune system through geomorphology, grain size, internal sedimentary structure, and the distribution of vegetation carried out between the years 2013-2014 and its comparison with existing data from 2004 [28] allow us to study the evolution of the ecosystem in the last 10 years and evaluate the effectiveness of the restoration measures applied.

The fundamental requirements for forming coastal sand dunes are an abundant sediment supply and sufficiently strong wind to transport it from the beach to the hinterland [46]. These requirements are given in the case of the Remolar beach, as shown by the dune system formed in the backshore of the beach. Morphologically, the dune system has originated a new primary dune, present throughout the beach as of 2006 (http:/ / www.icc.cat/vissir3/) and which remains until the completion of this work, and much of an embryonic dune ridge. This embryonic ridge appeared temporally interrupted by erosion scarps, as a result of winter storms. The profiles also show a volumetric increase (Table 1) of the dune system, which has resulted in aggradation and progradation processes (Figure 3) in most of the dune system. In this sense, we consider that the washover processes, originated during storms, are one of the main sediment supply processes at the landside of dunes. The effectiveness of the process is clearly observed in the two GPR profiles (Figure 6), which present reflectors in the embryonic and primary dunes that fill the interdunar spaces through the RF3 facies.

As for the sand, the grain size distribution shows (Figure 4) a mean grain size cent red over $350 \mu \mathrm{m}$ and showing an increase at the crest of the dune ridges $[47,48]$. The evolution of the granulometric distribution shows higher values in the dry beach decreasing towards the leeward areas of the primary dune (Figure 4). We interpret this decrease as the concentration of transport on the seaside of the primary dune [46-48]. The result of the concentration of sediment deposition on this side of the primary dune is observed in 
the GPR profiles with the presence of the RF2 facies [38]. This facies shows the growth and migration of the new primary dune formed since 2004, as can be seen visually in the 2006 photo (Figure S1, Supplementary Material). The distribution range of the mean grain sizes, between 296 and $471 \mathrm{~m}$, within the granulometric class of the medium sand [43], throughout the dune system explains the capacity of the area's active winds to transport practically the entire granulometric range of sediments contributed by marine dynamics. It is evident that the areas closer to the marine area (backshore, embryonic and primary dunes) show a better classification of sediments (Figure 5) with sorting values below 2.30 . The importance of the different processes acting in a dune system, such as the edaphization processes, supply of organic matter, and calcium carbonate animal remains (mainly snail shells), explain the low relationship between grain size and sorting of the sediment.

As mentioned above, the Remolar beach-dune system holds the contribution of sediment on the beaches by the inputs of sand by coastal drift from the mouth of the Llobregat River. Currently, the beach shows moderate progradation dynamics (RF5 facies, Figure 6), which in turn creates space on the dry beach and allows sediment to accumulate (RF2 facies in Figure 6) on the seaside of the embryonic dune that deposits sediments on the landside of the dune (RF3 facies in Figure 6). The embryonic and primary dunes of profiles 1 and 2 (Figure 6) show the formation and growth process by repeating the successive accretion cycles on the seaside and by the deposition of sediments by washover processes in the landside, a process that produces a gradual filling of the interdune depression. In all, reflective beaches, such as Remolar, are characterized by low waves and narrow width; they usually present a single embryonic ridge [46,47]. The interrelation between morphology and vegetation is observed in the crest of the different dune ridges, where the RF4 facies clearly appear, identified as facies originated by the deposition of sediment through vegetation and root activity [38]. In our case (Figure 7), it would be mainly due to the presence of Elymus farctus in the embryonic dune and of Medicago marina in the primary dune, two species with a large root volume. In addition to the relationship between dune morphology and vegetation, certain studies [49-51] have shown the relationship between grain size and plant zonation [52], in our case the textural differences between the crests of the embryonic and primary dunes contrast with the parts more internal to the dune system, due to the edaphic processes.

According to Reference [28] in 2004 at Remolar, due to anthropogenic disturbances, the typical disposition of plant communities was strongly altered, highly dislocated, highly impoverished into characteristic species, and bastardized by species that are not properly psammophilous. To solve the problem, in Reference [28], only the two dominant vegetation types have been differentiated, which are those corresponding to mobile and embryonic dunes (white dunes) and those that develop into more or less fixed or stabilized dunes (gray dunes). Vegetation from mobile and embryonic dunes includes two communities-the Cypero mucronati-Agropyretum juncei community and the Medicagini marinae-Ammophiletum australis community. The Cypero mucronati-Agropyretum juncei community is composed of Elymus farctus, accompanied by Cyperus capitatus, Polygonum maritimum, Sporobolus pungens, Euphorbia peplis, and Calystegia soldanella. The Medicagini marinae-Ammophiletum australis community is composed of marram grass, Ammophila arenaria, the most characteristic species of this community, but that in the beach of the Remolar is a rare species that forms some bush in the innermost zones, the remaining species of this community, as Echinophora spinosa, Medicago marina or Eryngium maritimum, being more represented. The vegetation of the more or less stabilized dunes is represented only by the community of Crucianelletum maritimae, composed of some shrub species, among them Crucianella maritima, accompanied by species like Helichryssum stoechas, that announce the transition towards the coastal pine forest.

In our study, we can observe that the identified plant communities showed (Figure 7), consistently between the different transects, an arrangement in parallel longitudinal bands, or zonation following the previously presented model $[29,35]$. In this sense, the interrelation 
between geomorphic controls and the spatial distribution of vegetation is highlighted as a main determinant of the development of the system [12,38,53-56].

The position of the vegetation of embryonic dunes (Cypero mucronati-Agropyretum juncei) stands up in our study in the form of an almost-continuous strip near the coast. The plants of this community are characterized by having a great capacity for colonization, given the harsh environmental conditions that determine the foredune [53,55]. González et al. [28] they already found this community then, but then it occupied a wider strip with a more inland location. It is worth mentioning the importance of this community as a nesting place for the Kentish plover (Charadrius alexandrinus), a species recorded in the Spanish Red Book of Birds [57] as a vulnerable species.

The vegetation characteristic of primary dunes (Medicagini marinae-Ammophiletum australis) was found in its expected location, occupying a continuous strip along the entire beach of Remolar, where the environmental conditions are not as extreme as in the foredune. The plant species of this community develop systems that guarantee efficient water use (xeromorphic leaves, extensive root systems), that allows a medium vegetation cover, thus stabilizing the primary dunes, increasing sedimentary deposition, and favoring their growth [51,53,55]. In 2004, González et al. [28] located this community in the same area of the Remolar where we currently found it, except in some areas where its location occupied a more interior position. The absence of the typical species of this community Ammophila arenaria and Euphorbia paralias has been confirmed, but there is a good representation of the rest of the species of this community, such as Medicago marina, Silene niceensis, or Eryngium maritimum.

The secondary dune community with Crucianella maritima is the best-represented plant assemblage on the Remolar beach, occupying the back of the primary dune community. Both in our study and in that of Gonzalez et al. [28], this community in the Remolar beach includes a good deal of Cyperus capitatus, a species most typically found in less evolved dunes. Probably, the legacy of continued trampling affects negatively the populations of Crucianella maritima and associated species, and favors the persistence of Cyperus capitatus. This plant, due to its rhizome system giving aerial tillers, better resists frequentation and human disturbance, and contributes to effectively restoring the dunes. This community appears widely distributed in the Remolar, occupying a large part of the area that would correspond to the Crucianelletum, in which has enlarged from 2005.

Behind the dunes, vegetation is more protected from the action of the wind and marine aerosols, and nutrients and water are better conserved by more efficient soils. Moreover, despite the access to the dune system is currently restricted; we still found a large area occupied by ruderal and opportunistic communities, as a vestige of the ancient anthropic pressure (Figure 7). All this allows for greater diversity, both in species and in ecological groups. Plant communities include shrubby species (chamaephytes) together with plants related to anthropogenic influence. Among these species, we found Plantago coronopus, Salsola kali, Bromus madridensis, and introduced species, such as Carpobrotus edulis. The highest degree of ruderalization is found in areas where the allien Ambrosia coronopifolia predominates, which (due to its rhizomatous nature) almost forms monospecific populations.

Finally, González et al. [28] mention "an incipient pine forest with low elevation but vigorous pine trees" see Figures S1 and S2 (Supplementary Material), which has been transformed into well-formed pine stands in a maquia shape, which is practically monospecific in nature with a high density and in which only shade-tolerant species appear in the understory, such as Pleurochaete squarrosa or Aetheorhiza bulbosa.

\section{Conclusions}

The restored coastal dunes of El Remolar beach have undergone a process of resilience. If we consider the definitions given above (see Section 1), the dune system studied would show a high degree of resilience, having recovered much of the initial characteristics of a coastal dune system: Morphology, vegetation, dynamic behavior, the interrelation between 
morphology and vegetation, and heterogeneity. Therefore, the good resilience ability made that the measures of restoration and regeneration applied have had success.

Specifically, at the sedimentological level, the system works in a "natural" way, with the formation of a new dune ridge (primary dune) present along the entire beach and parallel to the coastline, and an embryonic dune absent only in the sections eroded by sea storms. The restoration measures applied have proven to be an effective measure for increasing the volume of sand accumulated in the dune system, without the need for artificial nourishment actions. The GPR profiles show the binomial of progradation and aggradation that occurs in the formation and growth of the dune ridges, with accretion on the side of the dune and deposition by slides or washover processes on the land side of it.

The vegetation in the dune system has spontaneously improved during the last decade. The phytosociological results have differentiated seven well-established plant communities, occurring on the dune system in a functional way, i.e., set in bands parallel to the coast. But despite the imposed restoration measures, the anthropic influence manifested by the opportunistic and ruderal communities is still alive after a decade.

The dynamics of the beach-dune system, represented in the Remolar beach by the presence of the new dune ridges of primary and embryonic dunes and their specific plant communities, demonstrates the need for the geomorphological connectivity of the chain formed by the beach, the dry beach, the embryonic dune, and the primary dune. The interruption of this concatenation of morphologies produces a degradation of the entire system and its affectation both to the morphology and to the entire vegetation of the system.

Therefore, we consider that after ten years of maintaining the simple and cheap measures of restoration and protection, the effects of trampling have disappeared, and that the ecosystem has recovered and contains the biotic and abiotic resources to continue its development [20]. The aforementioned problems of introduction of typically anthropic plant types are currently generalized to most of the dune systems in the area [29].

Supplementary Materials: The following are available online at https:/ / www.mdpi.com/2077-131 2/9/2/113/s1.

Author Contributions: Conceptualization, J.M.N., J.R.L., S.V., C.B. and A.C.; methodology, S.V., J.M.N., J.R.L., C.B., R.L.; L.R. and A.C.; investigation, S.V., J.M.N., L.R. and A.C.; writing—original draft preparation, S.V., J.M.N. and A.C. All authors have read and agreed to the published version of the manuscript.

Funding: This research received no external funding.

Institutional Review Board Statement: Not applicable.

Informed Consent Statement: Not applicable.

Data Availability Statement: The data presented in this study are available upon request from the corresponding author. The data are not publicly available because part of them have been part of the Master thesis of the co-author S.V.

Acknowledgments: This work is based in part on the Master's thesis of the second co-author (S.V.), which has been adapted for publication and expanded with the inclusion of GPR profiles. We thank the "Area de Medi Ambient" of the Viladecans Council and the "Consorci dels Espais Naturals del Delta del Llobregat" for the facilities and help during the work for the Master's thesis and the subsequent work carried out in the work area of the Remolar and Cal Francés included in the Network Natura 2000 currently ZEC (Zona d'Especial Conservació) of the Llobregat Delta. This research received no specific grant from any funding agency, commercial or not-for-profit sectors. We are grateful to the three anonymous reviewers for their careful review and correction work, which has allowed us to improve the manuscript.

Conflicts of Interest: The authors declare no conflict of interest. 


\section{References}

1. Martínez, M.L.; Hesp, P.A.; Gallego-Fernández, J.B. Coastal Dunes: Human Impact and Need for Restoration. Environ. Probl. Solving 2013, 1, 1-14. [CrossRef]

2. Sytnik, O.; Stecchi, F. Disappearing coastal dunes: Tourism development and future challenges, a case-study from Ravenna, Italy. J. Coast. Conserv. 2014, 19, 715-727. [CrossRef]

3. Pérez-Maqueo, O.; Martínez, M.L.; Nahuacatl, R.C. Is the protection of beach and dune vegetation compatible with tourism? Tour Manag. 2017, 58, 175-183. [CrossRef]

4. Lithgow, D.; Martínez, M.L.; Gallego-Fernández, J.B.; Silva, R.; Ramírez-Vargas, D.L. Exploring the co-occurrence between coastal squeeze and coastal tourism in a changing climate and its consequences. Tour. Manag. 2019, 74, 43-54. [CrossRef]

5. Doody, J.P. Coastal squeeze and managed realignment in southeast England, does it tell us anything about the future? Ocean Coast. Manag. 2013, 79, 34-41. [CrossRef]

6. $\quad$ Lithgow, D.; Martínez, M.L.; Gallego-Fernández, J.B.; Hesp, P.A.; Flores, P.; Gachuz, S.; Rodríguez-Revelo, N.; Jiménez-Orocio, O.; Mendoza-González, G.; Álvarez-Molina, L.L. Linking restoration ecology with coastal dune restoration. Geomorphology 2013, 199, 214-224. [CrossRef]

7. Van Der Meulen, F.; Salman, A. Management of Mediterranean coastal dunes. Ocean Coast. Manag. 1996, 30, 177-195. [CrossRef]

8. Sanjaume, E.; Pardo, J.E. Degradación de Sistemas Dunares. Capítulo 24; Sanjaume, E., Gracia, F.J., Eds.; Sociedad Española de Geomorfología: Las dunas en España, Spain, 2011.

9. Morales, J.A. (Ed.) The Spanish Coastal System. Dynamic Processes, Sediments and Management; Springer International Publishing: Cham, Switzerland, 2019. [CrossRef]

10. Ley, C.; Gallego-Fernández, J.B.; Vidal, C. Manual de Restauración de Dunas Costeras. Ministerio de Medio Ambiente: Santander, Spain, 2007. Available online: https://www.miteco.gob.es/es/costas/publicaciones/manual_restauracion_dunas.aspx (accessed on 15 November 2020).

11. Gómez-Pina, G.; Muñoz-Pérez, J.J.; Ramírez, J.L.; Ley, C. Sand dune management problems and techniques, Spain. J. Coast. Res. 2002, SI36, 325-332. [CrossRef]

12. Gallego-Fernández, J.B.; Sánchez, I.A.; Ley, C. Restoration of isolated and small coastal sand dunes on the rocky coast of northern Spain. Ecol. Eng. 2011, 37, 1822-1832. [CrossRef]

13. Muñoz-Vallés, S.; Gallego-Fernández, J.B.; Dellafiore, C.M. Dunevulnerability in relation to tourism pressure in central Gulf of Cádiz (SW Spain), a case study. J. Coast. Res. 2011, 27, 243-251. [CrossRef]

14. Muñoz-Vallés, S.; Cambrollé, J. Successes and failures in the management of coastal dunes of SW Spain: Status analysis nine years after management decisions. Ecol. Eng. 2014, 71, 415-425. [CrossRef]

15. Garcia-Lozano, C.; Pintó, J. Current status and future restoration of coastal dune systems on the Catalan shoreline (Spain, NW Mediterranean Sea). J. Coast. Conserv. 2017, 22, 519-532. [CrossRef]

16. Mir-Gual, M.; Pons, G.X. Coast sandy strip fragmentation of a protected zone in the N of Mallorca (Western Mediterranean). J. Coast. Res. 2011, 64, 1367-1371.

17. Roig-Munar, F.X.; Prieto, J.; Ángel, M.; Perea, A.R.; Blázquez-Salom, M. Restauración de sistemas dunares en las islas Baleares (2000-2017): Una visión crítica. Investig. Geográficas 2018, 69, 119. [CrossRef]

18. Sanjaume, E.; Pardo, J.E. Erosión by human impacto $n$ the Valencian coastline. J. Coast. Res. 2005, 49, 76-82.

19. Psuty, N.P.; Silveira, T.M. Restoration of Coastal Foredunes, a Geomorphological Perspective: Ex-emples from New York and from New Jersey, USA. In Restoration of Coastal Dunes, Spring Series on Environmental Management; Martinez, M.L., Gallego-Fernández, J.B., Hesp, P.A., Eds.; Spring: Heidelberg, Germany, 2013; Chapter 3; pp. 33-47. [CrossRef]

20. Society for Ecological Restoration International Science \& Policy Working Group. The SER International Primer on Ecological Restoration. 2004. Available online: www.ser.org (accessed on 15 November 2020).

21. Keenleyside, K.A.; Dudley, N.; Cairns, S.; Hall, C.M.; Stolton, S. Restauración Ecológica Ppara Áreas Prote-gidas: Principios, Directrices y Buenas Practices; UICN: Gland, Switzerland, 2014.

22. Holling, C.S. Resilience and Stability of Ecological Systems. Annu. Rev. Ecol. Syst. 1973, 4, 1-23. [CrossRef]

23. Hernández, A. Evaluación de la Resiliencia en Ecosistemas Terrestres Degradados Encaminada a la Restauración Ecológica; Actas de la II Reunión Española de Ciencia de Sistemas: Valencia, Spain, 2002.

24. Sherman, D.J. Problems of scale in the modeling and interpretation of coastal dunes. Mar. Geol. 1995, 124, 339-349. [CrossRef]

25. Montoni, M.V.F.; Honaine, M.F.; Del Río, J.L. An Assessment of Spontaneous Vegetation Recovery in Aggregate Quarries in Coastal Sand Dunes in Buenos Aires Province, Argentina. Environ. Manag. 2014, 54, 180-193. [CrossRef]

26. Pratch, K.; Bartha, S.; Joyce, C.B.; Pysek, P.; van Diggelen, R.; Wiegleb, G. The role of spontaneous vegetation succession in ecosystem restoration: A perspective. Appl. Veg. Sci. 2001, 4, 111-114. [CrossRef]

27. Nordstrom, K.F.; Lampe, R.; Vandemark, L.M. Reestablishing Naturally Functioning Dunes on Developed Coasts. Environ. Manag. 2002, 25, 37-51. [CrossRef]

28. González, V.; del Hoyo, R.; Valverde, A.; Seguí, J.M. Estudi de la Vegetació de la Platja del Remolar (Viladecans); Ajuntament de Viladecans: Barcelona, Spain, 2005; 47p.

29. Garcia-Lozano, C.; Pintó, J.; Daunis-I-Estadella, P. Changes in coastal dune systems on the Catalan shoreline (Spain, NW Mediterranean Sea). Comparing dune landscapes between 1890 and 1960 with their current status. Estuar. Coast. Shelf Sci. 2018, 208, 235-247. [CrossRef] 
30. Breton, F.; Esteban, P.; Miralles, E. Rehabilitation of metropolitan beaches by local administrations in Catalonia: New trends in sustainable coastal management. J. Coast. Conserv. 2000, 6, 97-106.

31. CIRC. 2010 Estat de la Zona Costera a Catalunya. Generalitat de Catalunya. Available online: https://www.icgc.cat/es/ Administracion-y-empresa/Servicios/Riesgos-geologicos/Dinamica-de-la-costa/Libro-verde-del-Estado-de-la-zona-costerade-Catalunya-2010 (accessed on 15 November 2020).

32. Mendoza, E.T.; Jimenez, J.A. Clasificación de tormentas costeras para el litoral Catalán (Mediterráneo NO). Ingeniería. Hidráulica. Mexicana. 2008, 2, 21-32.

33. Mendoza, E.; Jiménez, J.A.; Mateo, J. A coastal storms intensity scale for the Catalan sea (NW Mediterranean). Nat. Hazards Earth Syst. Sci. 2011, 11, 2453-2462. [CrossRef]

34. Mendoza, E.T.; Jiménez, J.A. Regional geomorphic vulnerability analysis to storms for Catalan beaches. Civ. Eng. Mar. Eng. 2009, $162,127-135$.

35. De Bolòs, O. El Paisaje Vegetal Barcelonés; Cátedra Ciudad de Barcelona: Barcelona, Spain, 1962; 192p.

36. Trask, P.D. Mechanical analysis of sediments by centrifuge. Econ. Geol. 1930, 25, 581-599. [CrossRef]

37. McCann, D.M.; Jackson, P.D.; Fenning, P.J. Comparison of the seismic and ground probing radar methods in geological surveying. Proc. Inst. Elec. Eng. 1988, 135, 380-390. [CrossRef]

38. Bristow, C.; Neil Chroston, P.; Bailey, S.D. The Structure and Development of Foredunes on a Locally Prograding Coast: Insights from Ground-Penetrating Radar Surveys; Sedimentology: Norfolk, UK, 2000; Volume 47, pp. 923-944.

39. Hugenholtz, C.; Moorman, B.; Wolfe, S.A. Ground penetrating radar (GPR) imaging of the internal structure of an active parabolic sand dune. In Special Paper 432: Stratigraphic Analyses Using GPR; Geological Society of America: Boulder, CO, USA, 2007; pp. 35-45. [CrossRef]

40. Bouxin, G. Ginkgo, a multivariate analysis package. J. Veg. Sci. 2005, 16, 355-359. [CrossRef]

41. De Cáceres, M.; Oliva, F.; Font, X.; Vives, S. Ginkgo, a program for non-standard multivariate fuzzy analysis. Adv. Fuzzy Sets Syst. 2007, 2, 41-56.

42. Sokal, R.R.; Rohlf, J.F. Biometry: The Principles and Practice of Statistics in Biological Research, 3rd ed.; Freeman: New York, NY, USA, 1995.

43. Wentworth, C.K. A Scale of Grade and Class Terms for Clastic Sediments. J. Geol. 1922, 30, 377-392. [CrossRef]

44. De Cáceres, M.; Font, X.; Oliva, F. Assessing species diagnostic value in large data sets: A comparison between phi coefficient and Ochiai index. J. Veg. Sci. 2008, 19, 779-788. [CrossRef]

45. Rivas-Martínez, S.; Fernández-González, F.; Loidi, J.; Lousã, M.; Penas, A. Syntaxonomical checklist of vascular plant communities of Spain and Portugal to association level. Itinera Geobot. 2011, 14, 5-341.

46. Flor-Blanco, G.; Pando, L.; Morales, J.A.; Flor, G. Evolution of beach-dune fields systems following the construction of jetties in estuarine mouths (Cantabrian coast, NW Spain). Environ. Earth Sci. 2015, 73, 1317-1330. [CrossRef]

47. Arens, S. Patterns of sand transport on vegetated foredunes. Geomorphol. 1996, 17, 339-350. [CrossRef]

48. Arens, S.M.; Van Boxel, J.H.; Abuodha, J.O.Z. Changes in grain size of sand in transport over a foredune. Earth Surf. Process. Landforms 2002, 27, 1163-1175. [CrossRef]

49. Acosta, A.; Ercole, S.; Stanisci, A.; Pillar, V.D.P.; Blasi, C. Coastal Vegetation Zonation and Dune Morphology in Some Mediterranean Ecosystems. J. Coast. Res. 2007, 236, 1518-1524. [CrossRef]

50. Fenu, G.; Cogoni, D.; Ferrara, C.; Pinna, M.S.; Bacchetta, G. Relationships between coastal sand dune properties and plant community distribution: The case of Is Arenas (Sardinia). Plant Biosyst. Int. J. Deal. All Asp. Plant Biol. 2012, 146, 1-17. [CrossRef]

51. Acosta, A.T.R.; Blasi, C.; Stanisci, A. Spatial connectivity and boundary patterns in coastal dune vegetation in the Circeo National Park, Central Italy. J. Veg. Sci. 2000, 11, 149-154. [CrossRef]

52. Bertoni, D.; Biagioni, C.; Sarti, G.; Ciccarelli, D.; Ruocco, M. The role of sediment grain-size, mineralogy, and beach morphology on plant communities of two Mediterranean coastal dune systems. Ital. J. Geosci. 2014, 133, 271-281. [CrossRef]

53. Hesp, P. Surf zone, beach, and foredune interactions on the Australian South East Coast. J. Coast. Res. 1988, 3, 15-23.

54. Durán, O.; Moore, L.J. Vegetation controls on the maximum size of coastal dunes. Proc. Natl. Acad. Sci. USA 2013, 110, 17217-17222. [CrossRef] [PubMed]

55. Byrne, M.L.; McCann, S.B. Stratification and sedimentation in complex vegetated coastal dunes, Sa-ble Island, Nova Scotia. Sedim. Geol. 1990, 66, 165-179. [CrossRef]

56. Lalimi, F.Y.; Silvestri, S.; Moore, L.J.; Marani, M. Coupled topographic and vegetation patterns in coastal dunes: Remote sensing observations and ecomorphodynamic implications. J. Geophys. Res. Biogeosci. 2017, 122, 119-130. [CrossRef]

57. Figuerola, J.; Amat, J.A.; Diaz Caballero, J.A. Chorlitejo patinegro, Charadrius alexandrinus. In Libro Rojo de las Aves de España; Ma-droño, A., González, C., Atienza, J.C., Eds.; Dirección General para la Biodiversidad-SEO/BirdLife: Madrid, Spain, 2004. 